\title{
Correction to: Analysis of the role of the human papillomavirus 16/18 E7 protein assay in screening for cervical intraepithelial neoplasia: a case control study
}

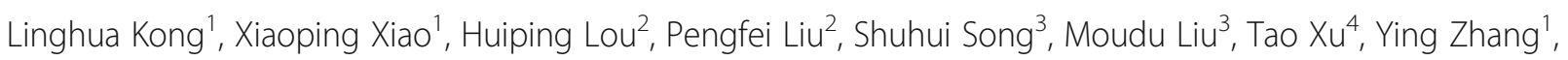
Caijuan Li $i^{1}$, Ruoli Guan ${ }^{1}$, Yan Li ${ }^{1}$, Xin Yu ${ }^{1}$, Haiyuan Liu', Qingbo Fan ${ }^{1}$, Honghui Shi ${ }^{1 *}$ and Lan Zhu ${ }^{1 *}$

\section{Correction to: BMC Cancer 20, 999 (2020) https://doi.org/10.1186/s12885-020-07483-z}

Following publication of the original article [1], the authors reported an error in affiliation 3. The correct affiliation 3 is: FAMID Biomedical Technology (Tianjin) Co., Ltd., No. 4, Haitai Development 2nd Road, Binhai Gaoxin District, Tianjin 300450, China.

The incorrect affiliation was also used in the method/ E7 protein assay section.

The original article [1] has been corrected.

\section{Author details}

'Department of Obstetrics and Gynecology, Peking Union Medical College Hospital, Chinese Academy of Medical Sciences, Shuaifuyuan No. 1, Dongcheng District, Beijing 100730, China. ${ }^{2}$ Department of Health Sciences, Peking Union Medical College Hospital, Chinese Academy of Medical Sciences, Shuaifuyuan No. 1, Dongcheng District, Beijing 100730, China. ${ }^{3}$ FAMID Biomedical Technology (Tianjin) Co., Ltd., No. 4, Haitai Development 2nd Road, Binhai Gaoxin District, Tianjin 300450, China. ${ }^{4}$ Institute of Basic Medical Sciences, Peking Union Medical College, Chinese Academy of Medical Sciences, 5 Dong Dan San Tiao, Beijing 100005, China.
Published online: 26 October 2020

\section{Reference}

1. Kong L, Xiao X, Lou H, et al. Analysis of the role of the human papillomavirus 16/18 E7 protein assay in screening for cervical intraepithelial neoplasia: a case control study. BMC Cancer. 2020;20:999. https://doi.org/10. 1186/s12885-020-07483-z.

The original article can be found online at https://doi.org/10.1186/s12885 020-07483-z.

*Correspondence: honghuishi@sina.com; zhu_julie@vip.sina.com 1 Department of Obstetrics and Gynecology, Peking Union Medical College Hospital, Chinese Academy of Medical Sciences, Shuaifuyuan No. 1, Dongcheng District, Beijing 100730, China

Full list of author information is available at the end of the article

C The Author(s). 2020 Open Access This article is licensed under a Creative Commons Attribution 4.0 International License, which permits use, sharing, adaptation, distribution and reproduction in any medium or format, as long as you give appropriate credit to the original author(s) and the source, provide a link to the Creative Commons licence, and indicate if changes were made. The images or other third party material in this article are included in the article's Creative Commons licence, unless indicated otherwise in a credit line to the material. If material is not included in the article's Creative Commons licence and your intended use is not permitted by statutory regulation or exceeds the permitted use, you will need to obtain permission directly from the copyright holder. To view a copy of this licence, visit http://creativecommons.org/licenses/by/4.0/. The Creative Commons Public Domain Dedication waiver (http://creativecommons.org/publicdomain/zero/1.0/) applies to the data made available in this article, unless otherwise stated in a credit line to the data. 